\title{
The Analysis of the Relationship between the Levels of Organizational Forgiveness and Organizational Commitment of Teachers
}

\author{
Sevim Öztürk \\ Department of Educational Science, Faculty of Education, İnonu University, Malatya, Turkey
}

Copyright $(2018$ by authors, all rights reserved. Authors agree that this article remains permanently open access under the terms of the Creative Commons Attribution License 4.0 International License

\begin{abstract}
In this research, it is aimed to determine the level of organizational forgiveness and organizational commitment of teachers and their relation. Descriptive method was used in the research. The working population of the research: Teachers who work in primary schools and high schools in the Battalgazi and Yeşilyurt district centers in Malatya province during the 2017-2018 academic year. A total of 450 teachers from 6 primary schools and 6 high schools selected by means of population sampling were included in the study. Two scales, "organizational forgiveness" and "organizational commitment", were used to collect the data of the study. In the analysis of the data, arithmetic mean standard deviation calculation, t-test and one-way analysis of variance (ANOVA) were performed. According to the findings obtained as a result of the research, it was seen that there was a significant difference between school type, education status and occupational seniority variables while there was no significant difference between teachers' organizational forgiveness and gender, marital status, number of children and field of study. Participants' organizational commitment levels were low at both overall sum and dimensions. There was a low level of positive relationship between organizational forgiveness and organizational commitment. Based on these findings, teachers' awareness about organizational forgiveness and the necessity of providing jobs in order to increase school commitment and suggestions such as personal rights, profession promotion, purchasing power and working conditions can be improved.
\end{abstract}

Keywords Teacher, Organizational Forgiveness, Organizational Commitment

\section{Introduction}

Education is important in terms of effective communication and interaction in organizations, the realization of organizational goals and meeting in a common denominator. Teachers' perceptions of the quality of the school environment influence their organizational commitment and therefore the performance of work and the quality of education offered at the school.

Organizational forgiveness is defined as "In the face of unfair behavior in the organization, the ability to put anger, frustration, and accusations in the collective abandonment and positive aspects of the future" [1]. Fehr and Gelfand [2], on the other hand, paired organizational forgiveness with organizational climate and emphasized that there are fair, compassionate and moderate behaviors among those who work in organizations with forgiving climates.

Studies conducted in the field reveal the importance of teachers' organizational commitment in terms of schools that are the application areas of education. Teachers' perceptions of the quality of the school environment influence their organizational commitment and therefore the performance of work and the quality of education offered at school [3]. In this study, the relationship between teachers' organizational forgiveness and organizational commitment is examined.

\section{Conceptual Framework}

\section{Organizational Forgiveness}

The forgiveness behavior and the subsequent tendency toward reconciliation, which are thought to be a response to injurious behavior on the level of individuals in organizations, are seen as a more useful option rather than avenging and maintaining anger [4]. In an organization faced with harm, injustice or error, it means to rediscover and improve the organization, to search for various solutions to restore and increase positive energy and activity, and to spread these solutions in the organization 
and to expand the capacity of forgiveness. Organizational forgiveness according to [2] and [5], it is a way to increase productivity, improve relationships among employees and remove or mitigate the negative feelings when hurtful events emerge [6].

Forgiveness is the case; it has been a research topic for theologians and philosophers in the past, but in recent years it has become a field of study in psychological counseling, attracting more attention to psychologists in recent years [7]. The concept of forgiveness has recently been mentioned as a simple phenomenon in the media, but it is emphasized that the field is a useful process that requires much effort in writing. Forgiveness includes a variety of meanings, including nervous soothing, diminished hatred of others, old perceptions and interpretations, and relief from learned answers. Although it does not have a lot of meaning, there is not yet a definition accepted by everyone for forgiveness. Definitions vary according to the viewpoints of scientists. In the definitions made about forgiveness, they emphasized the differences between similar concepts such as "forgiveness," "forgiveness," "excuse," "forgetting," "reconciliation," and "refusing any wrongdoing" [8]. At the same time, [9] regarded forgiveness as a behavior of adaptation and consider forgiveness as a psychological disorder [6]. According to another definition, forgiveness is expressed as "against the injustice of the faulty person, by giving negative feelings and judgments against the faulty person" [10].

Forgiveness is an active process that changes both forgiving and forgiven (culprit). It is also a conscious and willing process with emotional, behavioral, cognitive components [8]. There are different interpretations of the meaning of forgiveness in the literature. Forgiveness is to to improve the communication with the person making mistakes, to improve the communication with the person who made mistakes, to show valuable behavior, finally to get rid of the negative emotions, to get rid of aggression and to get rid of the feeling of revenge. The psychodynamic approach tends to base forgiveness on love. According to this approach, forgiveness is the departure from anger and aggression on the axis of compassion and benevolence. For the most hidden power that lies under your forgiveness is the principle of loving and unrecognized commitment. This point of view has more positive and even loving feelings towards harming [11].

According to Denham, Neal, Wilson, Pickering, Boyatzis (2005), there are cognitive, affective, behavioral and motivational dimensions of forgiveness. In this multidimensional structure, the transformation of the individual is motivated by cognitive and emotional judgments towards a criminal; the donor becomes motivated by positive social behaviors towards the criminal by removing himself from negative thoughts [12].

Forgiveness is a complex structure with both internal and interpersonal dimensions. [13].
Enright and his colleagues took the case of forgiveness as a personality; emotional, cognitive and behavioral aspects; positive and negative emotions, change of thought and behavior; McCullough et al. (2003) define affirmation as the orientation of negative motivation to conciliatory motivation [14]. Forgiveness is a complex structure with both internal and interpersonal dimensions.

In Worthington (1998), forgiveness refers to the relationship between emotion and motivation; one of them is two different directions of forgiveness: one of them is forgiveness and the other is emotional forgiveness. The person forgiven forgiveness forgives the guilty of punishment, while for emotional forgiveness negative emotions are left to positive emotions and an empathic approach is concerned. [14].

According to the definitions in the literature, forgiveness also shows a process characteristic. Luskin (2003) defines affirmation as a 9-step process [15]; Worthington (1998) identifies five steps.

Luskin summarizes these steps; to share experiences with trusted people, to hear responsibility, to know forgiveness peace, to understand the situation correctly, to apply some stress management techniques, to control their own feelings and thoughts, to give up waiting for something from other people, to find new ways to get rid of hurt feelings, to learn to look at things (like love, beauty, kindness) and to change the story you tell yourself; In Worthington's "Reach" model, painful recall, empathy with the painter, thinking that forgiveness is a kind of compromise, forgiveness and not forgiveness. [16].

Forgiveness in researchers in this regard is beneficial both in terms of individual and interpersonal relations; supporting the individual from psychological, physiological and social aspects, while contributing to a healthy, happy and peaceful life; it is also important to establish healthy relationships with the environment. [17]; [18]; [19]; [20]; [21].

It is stated that forgiveness also significantly influences individual, social and religious (spiritual) angles. For example, Braithwaite, Selby and Fincham (2011) found that there was a correlation between forgiveness and relationship satisfaction. In the studies of Raj, Elizabeth, and Padmakumari (2016), it was found that affirmation positively affected the psychological well-being, while Nemati, Mirnasab, and Bonab (2016) found that there was a significant positive correlation between maternal forgiveness and mental health. [22]; [23]; [24].

When these results are taken into account, forgiveness and behavior are more important in the teaching profession where interpersonal relationships are intensively experienced.

\section{Organizational commitment}

Occupational attitudes and behaviors of employees are seen as important in terms of organizational success. One of these behaviors is organizational commitment. 
In the related literature, there are many types of researches to explain these behaviors related to organizational outcomes. Again, many definitions have been made regarding organizational commitment. [25] (Aven, Parker and McEvoy 1993).

Grusky (1966) defines organizational commitment as "the power of the individual's knit bond" Wahn (1998); Kiesler, Sakumura and Salancik (1982) "behavioral actions resulting from the attachment attitudes of individuals" Reichers (1985); Bateman and Strasser (1984), "a function of perceived harmony between the individual and the organization" Bateman and Strasser (1984); Mowday et al. (1979) defined "employees as a high level of belief and acceptance of organizational goals and values, a desire to make intensive efforts for organizational purposes, and a strong desire to stay in the organization and maintain membership"[26]

Organizational commitment according to Allen and Meyer (1990); is a psychological condition that determines the relationship between the employees and the organization and determines the will to continue the membership of the organization. However, by integrating the goals of the organization and values, the responsibility of the institution is to achieve its goals [27]

Celep (200) defines organizational commitment as a behavior that reflects an individual's purpose and values beyond the formal and normative expectations that an individual expects from an individual [28]. Despite many definitions of organizational commitment, the most accepted definition in the literature is the definition by Porter, Mowday, and Steers (1979). According to this definition, organizational commitment is the desire to acknowledge the aims and values of the individual, and the organization, to make efforts to reach these goals and to maintain one's membership in the organization.

Given the definitions, organizational commitment; it is stated that there are three elements to be summarized as accepting the organizational goals and values, believing them, making efforts towards the achievement of the organizational goals and having a strong desire to continue the membership of the organization [26].

Findings reveal that some behavioral outcomes in the organization have a strong association with loyalty, while there is a strong and positive relationship among job satisfaction, motivation, participation and desire to stay in the organization and commitment, and a negative relationship between job change and absenteeism [29].

Working on organizational commitment, Randall (1987) investigated the level of commitment and the positive and negative consequences of these levels of job and mobility. In the study, organizational commitment was divided into three levels low, moderate and high. According to the result of the research, it is seen that in the low level of organizational commitment, there are no strong attitudes and behaviors that bind the worker, and the individuals are inadequate in the efforts related to the task and tend to research alternative job opportunities; at the level of moderate loyalty, the organizational identification and lack of commitment, the worker has experienced a confusion or conflict between responsibility and loyalty, where the system opposes reshaping itself, striving to maintain its identity as an individual; it has been found that those who work at high level of organizational commitment are connected to the strong attitudes and tendencies in the organization. [30].

Many types of research have been done on the dimensions of organizational commitment in the literature. In these researchers, the approaches of organizational behavioralists and social psychologists with different perspectives have led to the emergence of many different dimensions. While Konuyu dimensioned organizational behaviorists more in terms of commitment, social psychologists addressed behavioral commitment. [31].

There are different classifications made in this context: O'Reilly and Chatman (1986) classify organizational commitment as three dimensions: "Harmony", "identification" and "internalization"; Allen and Meyer (1997) classify them as "emotional commitment", "continuance commitment" and "normative commitment" [32].

While emotional attachment allows employees to accept the purpose and values of the organization and feel themselves as part of the organization, continuity implies that employees stay in the organization with cost anxiety and normative commitment refers to being in the organization because of the values and norms it possesses.

According to O'Reilly and Chatman's classification, cohesion refers to a superficial adherence to the weave. This dimension of commitment means that the individual maintains his or her commitment because of the cost of separation from the organization, or rather because it is found to be costly; identification means that the individual is proud to be a part of the organization and internalization means that the values of the individual and the organization are in harmony. [33].

Apart from these, Amitai Etzioni (1975) classify organizational commitment in the form of "alienating", "calculator" and "moral commitment"; Kanter (1968), on the other hand, categorize as "continuity", "clamping commitment" and "control commitment"[31].

In the loyalty scale developed by Balay and Balc1 (2000), it is seen that they are dimensioned as "harmony", "internalization" and "identification" [29].

Organizational commitment has significant benefits for both organizations and employees. According to Stum (1999), there are many factors that will connect employees. These are: wages and premiums as well as factors such as organizational culture, the balance between private life and work life, individual characteristics, general management policies, training and development possibilities in the workplace [34]. 
It has also been determined that whether the organizational commitment is positive or weak, many things such as job satisfaction, motivation, participation and desire to remain in the organization, negative behavioral consequences such as job change and absenteeism are revealed. [29].

Employees' organizational commitment can also facilitate the implementation of managerial decisions, such as enhancing social cohesion within the organization. Thus, both morale value and performance of the employee will be increased and the efficiency, success, and continuity of the organization will be ensured [35].

Studies show that there is a meaningful and positive relationship between organizational commitment and teacher's professional development and performance. Forgiveness is both a personal and an occupational shaping feature, such as an optimistic approach to having an individual's psychological status and having an internal reminder. In a teaching profession where personality traits, human relationships, and organizational characteristics are important factors, it is worth investigating the relationship between teachers' forgiveness characteristics and organizational commitment. Moreover, although there are many studies on this subject, the teachers have not been tested for these two variables. For this reason, research is important in this regard.

Organizational commitment is generally defined as integration into organizational goals. This integration is described as a desire to work hard for the organization and an irresistible desire to stay within the organization [36]. People who work on organizational commitment, describe the link within the organization as including a power and an organization that can integrate with the individual's being. This view, mobility commitment, is the desire to help, the maximum effort to reach the goal of the organization, and the appropriateness of the goals of the individual and the organization [37]. O'Reilly III and Chatman [33] classify organizational commitment as three dimensions: "Harmony", "identification" and "internalization" in the dimension; Allen and Meyer [32], have dimensioned as "continuous", "normative" and "emotional". Balay and Balc1 have dimensioned the commitment measure they developed as "harmony", "internalization" and "identification [39], while emotional commitment enables employees to accept their goals and values as part of their organization, continuity implies that employees stay in the organization with cost anxiety and normative commitment refers to being an organization because of the values and norms they possess. Compliance commitment expresses a superficial commitment to the organization.

This dimension of commitment means that the individual maintains his or her commitment because of the cost of separation from the organization, or rather because it is found to be costly; identification means that the individual is proud to be a part of the organization and internalization means that the values of the individual and the organization are in harmony [38]. When comparing different dimensions of organizational commitment, it is said that they actually express the same things as content; paralleled to the dimensions of continuous, normative and emotional attachment, the dimensions of identification, identification, and internalization seem to have similar characteristics.

Organizational commitment has significant benefits for both organizations and employees. According to Stum [40], there are many factors that will connect the employees. These may be material factors such as wages and premiums, as well as factors such as organizational culture, the balance between private life and work life, individual characteristics, general management policies, training and development opportunities at the workplace [41].

Studies show that there is a relationship between organizational commitment and the teacher's professional development and performance. The opportunities and working conditions provided to teachers also play an impressive role in organizational commitment. Forgiveness, on the other hand, defines an optimistic approach to the psychological state of an individual and the possession of an internal reminder; it is worth investigating the relationship between commitments.

\section{Purpose of the Research}

In this research, it is aimed to determine the level of organizational forgiveness and organizational commitment of teachers and their relation.

For this purpose, the following questions were asked:

- What are teachers' levels of organizational forgiveness: gender, marital status, number of children, branch, school level and type of education, education status and occupational seniority?

- What is the level of organizational commitment of teachers?

- Is there a meaningful relationship between teachers' organizational forgiveness and organizational commitment?

\section{The Importance of Research}

Teachers' organizational forgiveness and organizational commitment can also improve their professional performance and effectiveness as they will work more closely with the goals and values of the school. From this point of view, it is important to carry out such a study. In addition, the fact that there is no study that directly examines the relationship between forgiveness and commitment in the literature search makes the research more important in this respect.

\section{Method}

This research is descriptive in order to determine the 
relationship between organizational forgiveness and organizational commitment of teachers in terms of various variables. Correlational research model was used in the study. The study was carried out in primary schools and high schools in the Battalgazi and Yeşilyurt district centers of Malatya in the 2017-2018 academic year. 6 primary schools and 6 high schools were selected by means of sampling for the general population. While schools are being identified, the socio-economic and socio-cultural environment in which the school is located and the variety of school types are taken into consideration; volunteering in participant identification was taken as the basis. In this context, the sample of the research consists of a total of 450 teachers who participated in the survey from 12 schools.

Of the teachers who participated in the survey, $41.2 \%$ are female and $58.8 \%$ are male. It was determined that $10.1 \%$ of the respondents were single, $89.9 \%$ were married and $87.6 \%$ were children. While $35 \%$ of the participants are class teachers and $64.8 \%$ is the field of study teachers. $42.7 \%$ of them are working in the primary school, $6.9 \%$ in science education, $22.2 \%$ in Anatolian high school and $28.2 \%$ in vocational high school. When we look at the learning situation, $84.1 \%$ of them have undergraduate education and $15.9 \%$ of them have the graduate education. Again, 9.2\% teachers have $1-5$ years of seniority; $15 \%, 5-10$ years; $44.1 \%, 10-20$ years and $31.7 \%$ have 21 years or more seniority.

The data of the study were collected using two scales: "organizational forgiveness" and "organizational commitment". The organizational forgiveness scale was developed by Yasemin Kepenekçi and Funda Nayir in 2015. The scale consists of three dimensions and 21 items. The Cronbach Alpha coefficient found by the developers of the scale was .87 , while it was found to be .85 by the researcher.

The organizational commitment scale was developed by Allen and Mayer in 1990 and adapted to Turkish by Rabia Yeșilyurt in 2015. The scale consists of 3 dimensions and a total of 18 items. The Cronbach Alpha coefficient of the scale was found by Yeşilyurt in the range of .72-79 while it was found in the range of .73-78 by the researcher.

Of the 450 questionnaires distributed to be injured by the views of the participants, 367 returned, of which 20 were considered invalid for various reasons and the remaining 347 questionnaires were analyzed.

The data obtained in the study were subject to arithmetic mean $(\overline{\mathrm{X}})$, standard deviation (SS), one-way analysis of variance, Dunnet-C and Scheffe tests. In addition, the value of the effect size of eta-square $\left(\eta^{2}\right)$ was calculated. In addition, the eta-squared $\left(\eta^{2}\right)$ effect size value is calculated.

\section{Findings and Comment}

\section{Findings Related to the First Subproblem}

The first sub-problem of the research is arranged as "Does the level of organizational forgiveness of teachers show significant differences in terms of gender, marital status, number of children, branch, school type, education status and occupational seniority?".

The data obtained in this context were arranged and interpreted as the sub-probing response by subjecting to the arithmetic mean, standard deviation, t-test, one-way variance analysis (ANOVA) and Scheffe tests. Also, the eta-squared values are calculated to determine the effect size of the difference.

When we look at the results in Table 1, the forgiveness of the participants scored modestly with a mean of 31.36 , while the reasoning for justification was $=22.14$ and the rejection scale was low with $=17.91$ points.

While emphasizing acceptance of forgiveness in the questionnaire Items (1-10), it is emphasized to tolerance by taking into account the reasons of unfairness in the dimension of justification for forgiveness (Items 11-16), while emphasizing having a strong personality by the forgiveness of generality. If the forgiveness is in the dimension of rejection (Items 17-21), the reactions to injustice are indicated. Looking at these results, it is seen that the participants are more forgiving in the face of injustice.

According to these results, the high forgiving attitudes of teachers may be a reflection of their occupational roles or they may be due to the fact that they are in an organizational climate where human relations are experienced in intensity.

Table 1. Analysis Results Regarding Level of Organizational Forgiveness Perceived by Participants

\begin{tabular}{|clcccccc|}
\hline \multirow{2}{*}{ Scale } & \multicolumn{1}{c}{ Dimension } & Number of Items & Min. & Max. & $\bar{X}$ & Ss \\
\hline \multirow{3}{*}{ Organizational Forgiveness } & Forgiveness Accepting & 10 & 10 & 50 & $31.36(3.83)$ & 8.64 \\
\cline { 2 - 7 } & Forgiveness Justification & 6 & 6 & 30 & $22.14(3.69)$ & 5.08 \\
\cline { 2 - 7 } & Forgiveness Refusal & 5 & 5 & 25 & $17.91(3.58)$ & 4.03 \\
\hline & *The values in parentheses represent the average scores on a 5-point Likert scale. & \\
\hline
\end{tabular}




\section{(a) In Terms of Field of Gender Variable}

Table 2. Analysis of the Participants' Level of Organizational Forgiveness in Terms of Gender Change

\begin{tabular}{|c|c|c|c|c|c|c|c|c|}
\hline Scale Di & ension & Gender & $\mathbf{N}$ & $\bar{X}$ & SS & sd & $\mathbf{t}$ & $\mathbf{p}$ \\
\hline \multirow{6}{*}{ Organizational Forgiveness } & \multirow{2}{*}{ Forgiveness Accepting } & Female & 143 & 30.83 & 8.81 & \multirow{2}{*}{345} & \multirow{2}{*}{-.95} & \multirow{2}{*}{.339} \\
\hline & & Male & 204 & 31.73 & 8.52 & & & \\
\hline & \multirow{2}{*}{ Forgiveness Justification } & Female & 143 & 21.69 & 4.98 & \multirow{2}{*}{345} & \multirow{2}{*}{-1.38} & \multirow{2}{*}{.167} \\
\hline & & Male & 204 & 22.46 & 5.13 & & & \\
\hline & \multirow{2}{*}{ Forgiveness Refusal } & Female & 143 & 18.33 & 3.61 & \multirow{2}{*}{345} & \multirow{2}{*}{1.61} & \multirow{2}{*}{.108} \\
\hline & & Male & 204 & 17.62 & 4.29 & & & \\
\hline
\end{tabular}

According to Table 2, there is no significant relationship between teachers' forgiveness levels in terms of gender change $(\mathrm{p}>.05)$.However, in terms of accepting and forgiving forgiveness, it is observed that the average score of males is higher than that of females, whereas the score of females is higher than males by one point.

\section{(b) In Terms of Marital Status}

Table 3. Analysis of the Participants' Level of Organizational Forgiveness in Terms of Marital Status Change

\begin{tabular}{|c|c|c|c|c|c|c|c|c|c|}
\hline Scale Di & nension & Marital Status & $\mathbf{N}$ & $\bar{x}$ & SS & sd & $\mathbf{t}$ & $\mathbf{p}$ & $\eta^{2}$ \\
\hline \multirow{6}{*}{ Organizational Forgiveness } & \multirow{2}{*}{ Forgiveness Accepting } & Married & 312 & 31.34 & 8.45 & \multirow{2}{*}{345} & \multirow{2}{*}{-.130} & \multirow{2}{*}{.897} & \multirow{2}{*}{-} \\
\hline & & Single & 35 & 31.54 & $10: 27$ & & & & \\
\hline & \multirow{2}{*}{ Forgiveness Justification } & Married & 312 & 22.17 & 5.04 & \multirow{2}{*}{345} & \multirow{2}{*}{.324} & \multirow{2}{*}{.746} & \multirow{2}{*}{-} \\
\hline & & Single & 35 & 21.88 & 5.42 & & & & \\
\hline & \multirow{2}{*}{ Forgiveness Refusal } & Married & 312 & 17.85 & 4.01 & \multirow{2}{*}{345} & \multirow{2}{*}{.919} & \multirow{2}{*}{.359} & \multirow{2}{*}{-} \\
\hline & & Single & 35 & 18.51 & 4.25 & & & & \\
\hline
\end{tabular}

When looking at the values shown in Table 3, it has been found that there is no significant difference between teachers' forgiveness levels in terms of marital status change ( $p>.05)$. However, when we look at the dimensions in some respects, it is seen that single teachers are more forgiving with a very small point difference compared to married ones.

\section{(c) In Terms of Having a Child}

Table 4. Analysis of the Participants' Level of Organizational Forgiveness in Terms of In Terms of Having a Child Change

\begin{tabular}{|c|c|c|c|c|c|c|c|c|}
\hline Scale Di & ension & Having a Child & $\mathbf{N}$ & $\overline{\mathrm{X}}$ & SS & sd & $\mathbf{t}$ & $\mathbf{p}$ \\
\hline \multirow{6}{*}{ Organizational Forgiveness } & \multirow{2}{*}{ Forgiveness Accepting } & No children & 43 & 32.93. & 9.57 & \multirow{2}{*}{345} & \multirow{2}{*}{1.27} & \multirow{2}{*}{.204} \\
\hline & & Children Available & 304 & 31.14 & 8.49 & & & \\
\hline & \multirow{2}{*}{ Forgiveness Justification } & No children & 43 & 21.90 & 5.35 & \multirow{2}{*}{345} & \multirow{2}{*}{-.335} & \multirow{2}{*}{.738} \\
\hline & & Children Available & 304 & 22.18 & 5.04 & & & \\
\hline & \multirow{2}{*}{ Forgiveness Refusal } & No children & 43 & 18.62 & 4.45 & \multirow{2}{*}{345} & \multirow{2}{*}{1.231} & \multirow{2}{*}{.219} \\
\hline & & Children Available & 304 & 17.81 & 3.97 & & & \\
\hline
\end{tabular}

$* \mathrm{p}<.05$

When we look at the values in Table 4, it is seen that there is no significant difference between teachers' forgiveness levels in terms of child ownership ( $p>.05$ ). However, it is seen that teachers who have no children in the dimension of accepting and rejecting forgiveness and teachers who have children in the dimension of justifying forgiveness perceive themselves as more forgiving than others. 


\section{(d) In Terms of Field of Study Variable}

Table 5. Analysis of the Participants' Level of Organizational Forgiveness in Terms of Field of Study Variable Change

\begin{tabular}{|c|c|c|c|c|c|c|c|c|}
\hline \multicolumn{2}{|c|}{ Scale Dimension } & Field of study & $\mathbf{N}$ & $\bar{X}$ & SS & sd & t & $\mathbf{p}$ \\
\hline \multirow{3}{*}{ Organizational Forgiveness } & Forgiveness Accepting & $\begin{array}{c}\text { Class } \\
\text { Field of study }\end{array}$ & $\begin{array}{l}122 \\
225\end{array}$ & $\begin{array}{l}31.27 \\
31.40\end{array}$ & $\begin{array}{l}7.78 \\
9.09\end{array}$ & 345 & -1.34 & .894 \\
\hline & Forgiveness Justification & $\begin{array}{c}\text { Class } \\
\text { Field of study }\end{array}$ & $\begin{array}{l}122 \\
225\end{array}$ & $\begin{array}{l}21.95 \\
22.25\end{array}$ & $\begin{array}{l}5.17 \\
5.03\end{array}$ & 345 & -.537 & .592 \\
\hline & Forgiveness Refusal & $\begin{array}{c}\text { Class } \\
\text { Field of study }\end{array}$ & $\begin{array}{l}122 \\
225\end{array}$ & $\begin{array}{l}17.93 \\
17.91 \\
\end{array}$ & $\begin{array}{l}3.88 \\
4.12\end{array}$ & 345 & .501 & .959 \\
\hline
\end{tabular}

According to the data in Table 5, it is seen that there is no significant difference between teachers' forgiveness levels in terms of branch change $(\mathrm{p}>.05)$. However, it has been determined that there is a very small point difference in favor of the field of study teacher in some sizes.

\section{(e) In terms of Learning Level Variable}

Table 6. Analysis of the Participants' Level of Organizational Forgiveness in Terms of Learning Level Variable Change

\begin{tabular}{|c|c|c|c|c|c|c|c|c|c|}
\hline \multicolumn{2}{|c|}{ Scale Dimension } & Learning & $\mathbf{N}$ & $\overline{\mathrm{X}}$ & SS & sd & $\mathbf{t}$ & p & $\eta^{2}$ \\
\hline \multirow{6}{*}{ Organizational Forgiveness } & \multirow{2}{*}{ Forgiveness Accepting } & Undergraduate & 292 & 31.55 & 8.43 & \multirow{2}{*}{345} & \multirow{2}{*}{.969} & \multirow{2}{*}{.333} & \\
\hline & & Graduate & 55 & 30.32 & 9.68 & & & & \\
\hline & \multirow{2}{*}{ Forgiveness Justification } & Undergraduate & 292 & 21.90 & 4.99 & \multirow[b]{2}{*}{345} & \multirow[b]{2}{*}{-2.11} & \multirow{2}{*}{$.035^{*}$} & \multirow{2}{*}{.01} \\
\hline & & Graduate & 55 & 23.47 & 5.36 & & & & \\
\hline & \multirow[b]{2}{*}{ Forgiveness Refusal } & Undergraduate & 292 & 17.80 & 3.92 & \multirow[b]{2}{*}{345} & \multirow{2}{*}{-1.21} & \multirow[b]{2}{*}{.224} & \\
\hline & & Graduate & 55 & 18.52 & 4.58 & & & & \\
\hline
\end{tabular}

There was a significant relationship between teachers' organizational forgiveness and their learning status ( $\mathrm{p}<.05$, $\mathrm{t}=-2.11$ ). However, this relationship seems to have emerged only in the "justification" sub-dimension of organizational forgiveness. According to the calculated $\eta^{2}$ values (.01), it can be said that this effect is small. The education status of the participants was determined as undergraduate and graduate. From the above viewpoint, it is found that the teachers with the graduate education are more forgiving in two dimensions $(\bar{X}=23.47, \bar{X}=18.52)$ while the graduate graduates are higher than the acceptance of forgiveness $(\overline{\mathrm{X}}=31.55)$.

\section{(f) From the Point of View of the School Stage and the Change of Duty}

Table 7. Analysis of the Participants' Level of Organizational Forgiveness in Terms of School Stage and Type Variable Change

\begin{tabular}{|c|c|c|c|c|c|c|c|c|c|}
\hline Scale / I & iension & School Type & $\mathbf{N}$ & $\overline{\mathrm{X}}$ & Ss & $\mathbf{F}$ & $\mathbf{p}$ & Difference (Scheffe) & $\eta^{2}$ \\
\hline \multirow{12}{*}{$\begin{array}{l}\text { Organizational } \\
\text { Forgiveness }\end{array}$} & \multirow{4}{*}{$\begin{array}{c}\text { Forgiveness } \\
\text { Accept }\end{array}$} & 1. Primary school & 148 & 31.60 & 7.96 & \multirow{4}{*}{418} & \multirow{4}{*}{.740} & & \\
\hline & & \multirow{2}{*}{ 3. Anatolian High School } & 24 & 32.62 & 9.12 & & & & \\
\hline & & & 77 & 30.58 & 10.3 & & & & \\
\hline & & $\begin{array}{l}\text { 4. Vocational High } \\
\text { School }\end{array}$ & 98 & 31.29 & 8.12 & & & & \\
\hline & \multirow{4}{*}{$\begin{array}{l}\text { Forgiveness } \\
\text { Justification }\end{array}$} & \multirow{3}{*}{$\begin{array}{l}\text { 1. Primary school } \\
\text { 2. Science High School } \\
\text { 3. Anatolian High School }\end{array}$} & 148 & 22.34 & 5.13 & \multirow{4}{*}{.614} & \multirow{4}{*}{.606} & & \\
\hline & & & 24 & 22.00 & 5.19 & & & & \\
\hline & & & 77 & 21.48 & 5.35 & & & & \\
\hline & & $\begin{array}{l}\text { 4. Vocational High } \\
\text { School }\end{array}$ & 98 & 22.41 & 4.76 & & & & \\
\hline & \multirow{4}{*}{$\begin{array}{l}\text { Forgiveness } \\
\quad \text { Refusal }\end{array}$} & 1. Primary school & 148 & 18.22 & 3.71 & & & & \multirow{4}{*}{0.02} \\
\hline & & 2. Science High School & 24 & 17.95 & 4.10 & & & & \\
\hline & & 3. Anatolian High School & 77 & 18.53 & 4.35 & 1.98 & .040 & $3-4$ & \\
\hline & & $\begin{array}{l}\text { 4. Vocational High } \\
\text { School }\end{array}$ & 98 & 16.90 & 4.12 & & & & \\
\hline
\end{tabular}

According to the findings in Table 7, only the forgiveness of the teachers' organizational forgiveness and the school level and the type were found to be significant in the refusal $\left[\mathrm{F}_{(2-345)}=1.98 \mathrm{p}<.05\right]$ dimension. However, this difference has been evident in terms of the school type, which is not seen at the school level. According to the sheffe test to determine the difference between groups, it was determined that there is a difference between Anatolian high school teachers $(\bar{X}=18.53)$ and vocational high school teachers $(\bar{X}=16.90)$ in favor of Anatolian high school. In other dimensions, it has been seen 
that the teachers of the high school $(\overline{\mathrm{X}}=32.62)$ and the teachers of the vocational high school $(\overline{\mathrm{X}}=22.41)$ described themselves as more forgiving.

\section{(g) In Terms of Seniority Variable}

Table 8. Analysis of the Participants' Level of Organizational Forgiveness in Terms of Seniority Variable Change

\begin{tabular}{|c|c|c|c|c|c|c|c|c|c|}
\hline \multicolumn{2}{|c|}{ Scale / Dimension } & Seniority & $\mathbf{N}$ & $\bar{X}$ & Ss & $\mathbf{F}$ & $\mathbf{p}$ & Difference (Scheffe) & $\eta^{2}$ \\
\hline \multirow{12}{*}{$\begin{array}{c}\text { Organizational } \\
\text { Forgiveness }\end{array}$} & \multirow{4}{*}{$\begin{array}{c}\text { Forgiveness } \\
\text { Accept }\end{array}$} & $1-5$ years & 32 & 32.78 & 8.05 & \multirow{4}{*}{3.83} & \multirow{4}{*}{.010} & \multirow{4}{*}{$2-1$} & \multirow{4}{*}{0.32} \\
\hline & & $5-10$ years & 52 & 28.67 & 9.29 & & & & \\
\hline & & $10-20$ years & 153 & 32.71 & 8.03 & & & & \\
\hline & & Over 21 years & 110 & 30.33 & 8.97 & & & & \\
\hline & \multirow{4}{*}{$\begin{array}{l}\text { Forgiveness } \\
\text { Justification }\end{array}$} & $1-5$ years & 32 & 22.28 & 4.55 & \multirow{4}{*}{2.79} & \multirow{4}{*}{.040} & \multirow{4}{*}{$2-3$} & \multirow{4}{*}{0.2} \\
\hline & & $5-10$ years & 52 & 21.25 & 5.49 & & & & \\
\hline & & $10-20$ years & 153 & 22.98 & 4.68 & & & & \\
\hline & & Over 21 years & 110 & 21.38 & 5.41 & & & & \\
\hline & \multirow{4}{*}{$\begin{array}{l}\text { Forgiveness } \\
\text { Refusal }\end{array}$} & $1-5$ years & 32 & 19.12 & 3.25 & \multirow{4}{*}{1.53} & \multirow{4}{*}{.205} & & \\
\hline & & $5-10$ years & 52 & 17.65 & 4.13 & & & & \\
\hline & & $10-20$ years & 153 & 18.07 & 4.23 & & & & \\
\hline & & Over 21 years & 110 & 17.48 & 3.87 & & & & \\
\hline
\end{tabular}

In terms of seniority variable (Table 8), there was a significant difference between two levels of organizational forgiveness of teachers and seniority variable. This difference was found to be in the value of forgiveness acceptance $\left[\mathrm{F}_{(2-345)}=3.83 \mathrm{p}<.05\right]$ and in the level of justification for forgiveness $\left[\mathrm{F}_{(2-370)}=2.79 \mathrm{p}<.05\right]$. The difference according to the scheffe test was that between 1 and 5 years $(\bar{X}=32.78)$ and $5-10$ years $(\bar{X}=28.67)$ in the dimension of acceptance of forgiveness; it is seen that between 10 and 20 years $(\bar{x}=21.25)$ and between 10 and 20 years $(\bar{X}=22.98)$ are favorable for $10-20$ years in the dimension of forgiveness justification.

While there is no significant difference in seniority in the refusal dimension of forgiveness; it is seen that the forgiveness levels of teachers with $1-5$ years of seniority at this dimension are lower than $\mathrm{x}=19.12$.

In general, the findings obtained in this context are as follows; it was seen that there was a significant difference between school type, education status, and occupational seniority variables while there was no significant difference between teachers' organizational forgiveness and gender, marital status, number of children and branches. However, this difference has occurred at a low level of effectiveness.

\section{Findings Related to the Second Subproblem}

The second subproblem of the research is arranged as
"What is the level of organizational commitment of teachers?" The data obtained to find the answer to this question are subject to the arithmetic mean, standard deviation and t-test analysis.

Table 9. Descriptive Analysis Results of Teachers' Level of Organizational commitment

\begin{tabular}{|cccccccc|}
\hline Scale & Dimension & $\begin{array}{c}\text { Number of } \\
\text { Items }\end{array}$ & Min. Max. & $\overline{\mathrm{X}}$ & Ss \\
\hline \multirow{2}{*}{$\begin{array}{c}\text { Organizational } \\
\text { commitment }\end{array}$} & $\begin{array}{c}\text { Emotional } \\
\text { commitment }\end{array}$ & 6 & 11 & 29 & $\begin{array}{c}20.59 \\
(3.57)\end{array}$ & 3.15 \\
\cline { 2 - 7 } & $\begin{array}{c}\text { Continuing } \\
\text { commitment }\end{array}$ & 6 & 6 & 30 & $\begin{array}{c}17.10 \\
(2.85)\end{array}$ & 4.38 \\
\cline { 2 - 7 } & $\begin{array}{c}\text { Normative } \\
\text { commitment }\end{array}$ & 6 & 5 & 25 & $\begin{array}{c}17.85 \\
(2.97)\end{array}$ & 5.07 \\
\hline
\end{tabular}

*The values in parentheses represent the average scores on a 5-point Likert scale.

According to the table 9, the participants' scores on organizational commitment were found to be low in all dimensions, while the emotional attachment dimension was scored higher by the arithmetic mean of 20.59 than the others.

Each of the three dimensions of the questionnaire consists of 6 Items. In the aspect of emotional attachment (1-6 Items), while being happy to work in the institution and meeting in common purpose is emphasized; it is emphasized that because of the lack of alternative employment opportunities in the aspect of continuity (7-12 Items), it is a necessity to satisfy the existing job. 
Normative commitment (13-18 Items), such as gratitude towards the school, commitment feelings, and moral obligation are treated. According to the results in the table, participants seem to be more attached to the arrow than to the emotional direction.

According to these results; the fact that the emotional attachment of teachers is relatively moderate in relation to other dimensions, they are happy to work at school and integrate with the purposes of the school, while the low attendance and normative commitment seem to be a contradiction. Low attendance may be interpreted as a tendency for teachers to maintain this commitment because of their commitment to the school, even though they are not very integrated with the values of the school in normative commitment, in which teachers might consider to be in school as a necessity of volunteerism and think that there are no other options.

\section{Findings Related to the Third Subproblem}

The third sub-problem of the study is arranged as Is there a meaningful relationship between teachers' organizational forgiveness and organizational commitment?

The data of this subproblem was subjected to correlation analysis and regulated and interpreted as sub problematic response.

Table 10. Correlation values of Teachers' Organizational Forgiveness and Organizational commitment

\begin{tabular}{|c|c|c|c|c|}
\hline Variable & $\begin{array}{c}\text { Total } \\
\text { commitment }\end{array}$ & $\begin{array}{c}\text { Emotional } \\
\text { commitment }\end{array}$ & $\begin{array}{l}\text { Continuation } \\
\text { commitment }\end{array}$ & $\begin{array}{l}\text { Normative } \\
\text { commitment }\end{array}$ \\
\hline $\begin{array}{c}\text { Total } \\
\text { Forgiveness }\end{array}$ & $.142^{* *}$ & $.177 * *$ & $-.087 * *$ & $.221 * *$ \\
\hline $\begin{array}{c}\text { Forgiveness } \\
\text { Accepting }\end{array}$ & $.178 * *$ & $.177 * *$ & $-.052 * *$ & $.256^{* *}$ \\
\hline $\begin{array}{l}\text { Forgiveness } \\
\text { Justification }\end{array}$ & $.149 * *$ & $.164 * *$ & $-.008 * *$ & $-.173 * *$ \\
\hline $\begin{array}{c}\text { Forgiveness } \\
\text { Refusal }\end{array}$ & $-.072 * *$ & $.031^{* *}$ & $-.180 * *$ & $.006 * *$ \\
\hline \multicolumn{5}{|c|}{$* * \mathrm{p}<.01$} \\
\hline
\end{tabular}

In the analysis of the correlation between organizational forgiveness and organizational commitment, there was a low level of positive correlation at the level of $\mathrm{r}=.142$ (Table 10)

In the context of the data in Table 10, when we look at the relationship dimensions between organizational forgiveness and organizational commitment, a positive relationship was found between the total score of organizational forgiveness and emotional commitment ( $\mathrm{r}$ $=.177$ ), while a negative relationship between continuing commitment (-.087) and normative commitment (.221).

According to these results, there is a positive but low level of relationship between organizational forgiveness and "emotional" and "normative" commitment dimensions of organizational commitment; there was a negative relationship between continuing commitment and a low level of relationship.
When we look at the relationship between organizational commitment and sub-dimensions of organizational forgiveness, organizational commitment score and organizational forgiveness show a positive relationship between "forgiveness accepting" $(\mathrm{r}=.178)$ and "forgiveness justification" $(r=.149)(r=-.072)$ in the dimension of "forgiveness refusal".

According to these findings, we conclude that there is a significant relationship between organizational forgiveness and organizational commitment on the basis of both the total sum and the dimensions, but this relationship is not very strong.

Teachers have a low level of view in terms of organizational forgiveness and organizational commitment, resulting in a naturally low level of relationship between them.

\section{Conclusions, Discussion and Recommendations}

In this research, it was aimed to examine some personal variables and to determine the direction and power of the relationship between teachers' organizational forgiveness and organizational commitment levels .The research is designed descriptively. In the research, relational scanning model was used. The study was conducted in elementary and high school. The sample of the research consists of a total of 450 teachers.

The data of the study were collected on two scales called "organizational forgiveness" and "organizational commitment" .The Cronbach Alpha coefficient of the organizational forgiveness scale was .87 and the organizational commitment scale was .78 .

The data obtained in the study are given as arithmetic mean $(\bar{X})$, standard deviation (SS), one way variance analysis, Dunnet-C and Scheffe tests. In addition, the value of the effect size of eta-square $\left(\eta^{2}\right)$ is calculated.

As a result of the research, it was found that there was no significant difference in the levels of organizational forgiveness: gender, marital status, number of children and their branches, while it was found that there was a meaningful but low effect level of difference in terms of school type, education status and occupational seniority. Teachers' organizational commitment levels were found to be low in the positive direction, while organizational forgiveness and organizational commitment were found to be at a low level in the positive direction.

When we look at the findings obtained in this context in terms of the information in the literature and the results of the research, the results of the research are summarized below:

While there is no significant difference between teachers' organizational forgiveness and gender, marital status, number of children and branch variables; school type, education status and occupational seniority variables, 
however, this difference has occurred at a low level of effectiveness.

When we look at the summer of the area, we can see that the work done in this area is not very common. In a similar study conducted by Kepenekçi and Nayır [42], there was no significant relationship between variables of gender, marital status and number of children and forgiveness in supporting research findings. Again, in studies conducted in the field of psychology, the concept of "self-forgiveness" was used and this concept was associated with personal variables. In this context, there is no relation between self-forgiveness and gender change in Macaskill [43] and Ranganathan and Todorov [44] studies.

In the study, a significant relationship was found between organizational forgiveness and seniority and education level variables. In studies of Çetinkaya and Şener [45], Akın, et al. [46] and Azar, et al. [47], positive correlations were found between variables of seniority, marital status and education status in support of research findings.

However, Mauger, et al. [48] and Tangney, et al. [49] found that there was a favorable relationship between self-forgiveness and sex change in favor of women.

In another finding found in the survey, the level of organizational commitment of participants was low, both by overall sum and by dimensions. However, the emotional attachment dimension is scored at a relatively higher level than the others. When we look at some of the studies conducted in this context, the results of the research conducted by Balay [29], Canipe [50], Çavuş and Gürdoğan [51], Yüceler [52] and Sezgin, [53], show that the organizational commitment levels of the participants were found to be moderate, with a slightly higher level of emotional attachment.

As a result of the research, there was a low level of positive relationship between organizational forgiveness and organizational commitment. This relationship was observed between organizational forgiveness and organizational commitment positively but lowly between the dimensions of "emotional" and "normative" commitment, negative between continuity and low level.

In the literature, there are many types of researches that investigate the relationship between organizational commitment and trust, job satisfaction, school climate, school culture, while there is no study that shows an association between organizational forgiveness and organizational commitment. Almost all of these surveys have found significant relationships between commitment and the variable associated with it.

According to these results, the low level of forgiveness of the participants may be due to the specific qualities of the teaching profession. The teacher is a profession where human relations are intensively experienced; they are always right, honesty, fairness, and courtesy in their relationships with students, teachers, administrators and parents, and they cannot remain insensitive to their wrong-unjust behavior and attitude in their duties and always feel responsible for correcting themselves. From this point of view, the fact that the level of forgiveness is low can be interpreted in this context.

It is also seen that organizational forgiveness does not predict commitment. It can be concluded that emotional attachment in research is higher than normative commitment and that teachers are not very happy about doing their job although they actually like their profession. In addition to the lover they have heard about the profession, they find that their opportunities for the profession are inadequate, indicating that they are more accountable and more pragmatist. An interpretation can be made that these attitudes lead to a low level of continuity and normative dimension.

Based on research findings:

(1) Teachers can create awareness about organizational forgiveness. This feature can create a certain degree of effectiveness in the practice of the teaching profession. It should be emphasized that this feature is also different from "tolerance" and "ignoring". Teachers should be made to feel that conscientious forgiveness is necessary for the student to be able to make mistakes and to establish more healthy communication in and out of school relationships.

(2) Proposals can be developed to increase teachers' commitment to the school, such as the provision of occupational rights, professional advancement, purchasing power and working conditions.

It is also possible to conduct research that tests the relationship between forgiveness and/or commitment and the success of the student and success in reading.

\section{REFERENCES}

[1] Cameron, K. and Caza, A. (2002). Organizational and leadership virtues and the role of forgiveness. Journal of Leadership \& Organizational Studies, 9(1), 33-48.

[2] Fehr, R. and Gelfand, M J. (2012). The forgiving organization: A multilevel model of forgiveness at work. Academy of Management Review, 37(4), 664-688.

[3] Hoy, W. K., and Miskel, C. G. (1987). Educational administration: Theory, research, and practice (4th ed.). New York: McGraw-Hill.

[4] Palanski, M. (2011). Forgiveness and Reconciliation in the Workplace: A Multi-Level Perspective and Research Agenda. Journal of Business Ethics, 109(3), 275-287.

[5] Zechmeister, J. S., and Romero, C. (2002). Victim and offender accounts of interpersonal conflict; Autobiographical narratives of forgiveness and unforgiveness. Journal of Personality and Social Psychology, 82, 675-686 
[6] Burgaz, B. (2016). Organizational Forgiveness and its implications. Educational Sciences Item as a gift to Professor Dr. Mustafa Aydin 1, 67-84.

[7] McCullough, M. E., Kurzban, R. and Tabak, B. A. (2013). Cognitive systems for revenge and forgiveness. Behavioral and Brain Sciences, 36, 1-58.

[8] Ayten, Ali (2009), "Forgiveness and Religion: An Empirical Study on Relation to Forgiveness and Religiosity ", M. U., Theology Faculty Journal 37 (2009/2), 111128

[9] Thompson, L.Y., Snyder, C.R., Hoffman, L., Michael, S.T., Rasmussen, H.N., Billings, L. S., et al. (2005). Dispositional forgiveness of self, others, and situations. Journal of Personality, 73, 313-360.

[10] Enright, R.D., Eastin, D.L., Golden, S., Sarinopoulos, I. and Freedman, S. R. (1992). Interpersonal Forgiveness with in the Helping Professions: An Attempt to Resolve Differences of Opinion. Counseling and Values, 36, 84 103.

[11] Sarıçam, H. and Biçer, B (2015). Ethical Value of Forgiveness and Explanatory Role of Self-understanding. Gazi University Journal of Education Faculty, 35(1): 109-122 (2015)

[12] Denham, K., Neal, B., Wilson, S., Pickering, C., Boyatzis, (2005). "Emotional Development and Forgiveness in Children: Emerging Evidence", Everett L.Worthington, Jr. (Ed.), In Handbook of Forgiveness, Newyork: Routledge, 127-142.

[13] Tagney, A.L., Boone, R., Dearing.(2005). "Forgiving the Self: Conceptual Issues and Empirical Findings", Everett L.Worthington, Jr. (Ed.), In Handbook of Forgiveness, Newyork: Routledge, 143-158.

[14] Huia E.K.P. \& Chaub T.S. (2009). "The impact of a forgiveness intervention with Hong Kong Chinese children hurt in interpersonal relationships", British Journal of Guidance \& Counselling, Vol. 37, No. 2, 141-156.

[15] Kymenlaakso, I.V., (2012). "Forgiveness as a leadership tool", Global Conference on Business and Finance Proceedings, Vol. 7, No. 1, 432-445.

[16] Kara, E. (2009) “Dini ve Psikolojik Açıdan Bağışlayıcılığın Terapötik Değeri”, Uluslararası Sosyal Araştırmalar Dergisi, 2, 8, 221-229.

[17] McCullough, M.E. \&. Rachal, K.C. \& Sandage,S.J. \&. Worthington, E.L.\& Brown, S.W. \& Hight, T.L. (1998). "Interpersonal forgiving in close relationships: II. Theoretical elaboration and measurement", Journal of Personality and Social Psychology, 75, 1586-1603.

[18] Webb, J.R. \& Robinson, E.A.R. \& Brower, J.R. (2011). "Mental Health, not Social Support, Mediates the Forgiveness-Alcohol Outcome Relationship", Psychology of Addictive Behaviors, Vol 25, 3, Sep 2011, 462-473, DOI:10.1037/a0022502.

[19] Temeshok, L.R. \& Wald, R.L. (2005). "Forgiveness and Health in Persons Living With HIV/AIDS”, Everett

[20] Ryan, R. B. \& Kumar, V.K. (2005). "Willingness to forgive: Relationships with mood, anxiety and severity of symptoms", Mental Health, Religion \& Culture 8, 1, 13-16.
[21] Toussaint, L. \& Shields, G. S. \&, Dorn, G. \& Slavich, G.M. (2014). "Effects of Lifetime Stress Exposure on Mental and Physical Health İn Young Adulthood: How Stress Degrades and Forgiveness Protects Health", Journal of Health Psychology, 19, 1-11, DOI: 10.1177/1359105314544132

[22] Braithwaite, S.R.\& Selby, E.A. \& Fincham, F.D. (2011). "Forgiveness and Relationship Satisfaction: Mediating Mechanisms", Journal of Family Psychology, 25, 4, 551-559, DOI: $10.1037 / \mathrm{a} 0024526$.

[23] Raj, P. \& Elizabeth,C.S. \&, Padmakumari, P. (2016) "Mental Health Through Forgiveness: Exploring the Roots and Benefits", Cogent Psychology, 3, 1-16, (2016), DOİ: 10.1080/23311908, 1153817.

[24] Nemati, S. \&, Mirnasab, M.M. \& Bonab, B.G. (2016). “The Relationship between Dimensions of Forgiveness with Mental Health in Mothers of Children with Intellectual and Developmental Disabilities", Journal of Education and Learning, 5, 4, 15-20, DOI: 10.5539/jel.v5n4p15.

[25] Aven, F. F. \& Parker, \& B. Mcebvoy, G. M. (1993). Gender and attitudinal commitment to organizations: A meta analysis., Journal of Applied Psycholog. 72, ss. 642-648.

[26] Mowday, R. \& Steers, R. \& Porter, L. (1979). The measurement of organizational commitment.Journal of Vocational Behavior. 14, ss. 224-247.

[27] Buchanan, B. (1974). "Building Organizational Commitment: The Socialization of Managers in Work Organizations", Administrative Science Quarterly, 19, ss. 533-538.

[28] Celep, C. (2000). Eğitimde Örgütsel Adanma ve Ögretmenler, Anı Yayıncılık, Ankara.

[29] Balay, R. (2000). Yönetici ve Öğretmenlerde Örgütsel Bağlılık, Ankara: Nobel Yayınları.

[30] Randall, D. M. (1987). Commitment and the organization: The organization man revisited.Academy of Management Review. 12(3), ss. 460-471.

[31] Gül, H. (2002). Örgütsel bağlılık yaklaşımlarının mukayesesi ve değerlendirmesi. Ege Üniversitesi Ege Akademik Bakış Dergisi. 2(1), s. 42

[32] Allen \& Meyer (1997) The measurement and antecedents of affective, continuance and normative commitment to the organization, s.11)

[33] O'Reilly, C. \& Chatman, J. (1986). Organizational commitment and psychological attachment: The effect of compliance, identification and internalization on prosocial behavior. Journal of Applied Psycholog.71(3), ss. 492-499.

[34] Durna, U. \& Eren, V. (2005). Üç Bağlılık Unsuru Ekseninde Örgütsel Bağlılık. Doğuş Üniversitesi Dergisi, 6 (2): 210-219.

[35] Somuncu, F. (2008). Örgütsel bağl1lık ve örgütsel bağl1lığ geliştirme araçları: özel bir hizmet işletmesinde araştırma. (Yayımlanmamış yüksek lisans tezi), Eskişehir: Anadolu Üniversitesi.

[36] Porter, L. W., Steers, R. M., Mowday, R. T., Boulian, P. V. Organiza- tional commitment, job satisfaction, and turnover among psychiatric technicians. Journal of Applied Psychology, 1974, 59, 603-609. 
[37] Karahan, A. (2008). Studying the Relationship Between Leadership and Organizational Loyalty at Hospitals. Journal of Social Sciences. 10 (1): 145-162

[38] O'Reilly III, C. A. and Chatman, J. (1986). Organizational commitment and psychological attachment: The effects of compliance, identification, and internalization on prosocial behavior. Journal of applied psychology, 71(3), 492-499.

[39] Allen, N. J., \& Meyer, J. P. (1990). The measurement and antecedents of affective, continuance, and normative commitment to the organization. Journal of Occupational Psychology, 63(1), 1-18.

[40] Balc1, A. (2000). Organizational Socialization: Theory, Strategy, and Tactics. Ankara: Pegem A Publishing.

[41] Stum, D. L. (1999) Workforce Commitment: Strategies for the New Work Order. Strategy \&Leadership, 27 (1): 5-7.

[42] Durna, U. and Eren, V. (2005). Organizational Commitment in the Axis of Three Commitments. Journal of Dogus University, 6 (2): 210-219.

[43] Kepenekçi, Y. K. and Nayir, K. F. (2015). Development of the organizational forgiveness scale and teachers' views on organizational forgiveness. Mersin University Journal of the Faculty of Education, 11(3), 922-934.

[44] Macaskill, A., Maltby, J. and Day, L. (2002). Forgiveness of Self and Others and Emotional Empathy. The Journal of Social Psychology, 142 (5), 663-665.

[45] Rangganadhan, A.R. and Todorov, N. (2010). Personality and Self-Forgiveness: The Roles of Shame, Guilt, Empathy and Conciliatory Behavior. Journal of Social and Clinical Psychology, 29 (1), 1-22.

[46] Cetinkaya, F. and Sener E. (2016). The relationship between the tendency to forgive in working life and emotional labor. Kastamonu University Faculty of Economics and Administrative Sciences journal. 1(1), 14.
[47] Akın, M., Özdevecioğlu, M. and Ünlü, O. (2012). The intent to revenge in organizations and the tendency to forgive relate to mental health. Amme Idaresi journal, 45(1), 77-79

[48] Azar, F. and Mullet, E. (2002). Muslim and Christian in Lebanon: Common Views Regarding Political Issues. Journal of Peace Research, 39, 755-766.

[49] Mauger, P. A., Perry, J. E., Freeman, T., Grove, D. C., \& et al. (1992). The measurement of forgiveness: Preliminary research. Journal of Psychology and Christianity, 11(2), 170-180.

[50] Tangney, J.P., Boone, A.L., and Dearing, R. (2005). Forgiving the Self: Conceptual Issues and Empirical Findings. In E.L. Worthington Jr (Ed.), Handbook of Forgiveness (p.143-159). New York: Routledge.

[51] Balay, R. (2000). Organizational Commitment to Managers and Teachers. Ankara: Nobel Publishing and Distribution.

[52] Canipe, J. S. (2006). Relationships among trust, organizational commitment, perceived organizational support, and turnover intentions (UMI No. 3211758). Unpublished doctoral dissertation, Alliant International University, San Diego, CA.

[53] Çavuş, Ş. and Gürdoğan, A. (2008). The relationship between organizational culture and organizational commitment: Research in a five-star hotel operation. Trade and Tourism Education Journal 1(1), 18-34.

[54] Yüceler, A. (2009). The relationship between organizational commitment and organizational climate: A theoretical and practical study. Selçuk University Social Sciences Institute Journal. 22, 445-458.

[55] Sezgin, F. (2009). Examining the relationship between teacher organizational commitment and school health in Turkish primary schools. Educational Research and Evaluation, 15(2), 185201. 